\title{
PERAN FINTECH DALAM MENINGKATKAN KEUANGAN INKLUSIF PADA UKM DI KABUPATEN PAMEKASAN
}

\author{
Purwanto $^{1 *}$, Ach Resa Rachrizi ${ }^{2}$, Isnain Bustaram ${ }^{3}$ \\ Universitas Madura, \\ Pamekasan, Madura, Indonesia \\ purwanto@unira.ac.id*
}

\begin{abstract}
Financial inclusion in UMKM in the pamekasan district. In this study, researchers took 4 samples randomly, from cooperatives and small and medium enterprise offices. Analysis of the data used in this study was to use data reduction then data presentation and the last was conclusions. The results of the research were that of the four informants as a whole receiving well with the presence of fintech because fintech can facilitate transactions. Fintech also provides many benefits for UMKM as well as more benefits from UMKM. The more efficient and effective business activities that made applied fintech and the development of the era require businesses to use fintech. Of the many advantages of fintech, there were certainly disadvantages, one of which was when the financial technology was problematic, it must be repaired and requires some time. Not only that, human resources that lack mastery of fintech made business people have to provide insight into fintech.
\end{abstract}

Keyword: Fintech, Financial Inclusion, UMKM

\section{PENDAHULUAN}

Perkembagan teknologi saat ini sangat berkembang dengan pesat secara signifikan, tidak hanya di Indonesia tetapi dunia juga merasakan perkembangan teknologi yang setiap waktunya berubah. Salah satunya yaitu pada sektor keuangan. Misalnya pada fintech (Financial technology) yang merupakan teknologi untuk mendukung layanan jasa keuangan. Perkembangan fintech banyak memunculkan inovasi, aplikasi dalam layanan keuangan, seperti alat pembayaran, alat pinjaman dan lain-lain yang mulai terkenal pada masa digital ini.Sebagai salah satu bentuk penerapan teknologi informasi di bidang keuangan.Fintech memiliki fungsi beragam, sebagian ada yang didirikan oleh perusahaan berbasis konvensional, tetapi tidak sedikit pula yang merupakan perusahaan rintisan atau startup yang diyakini mampu dengan cepat berkembang secara cepat. Saat ini fintech mampu melayani electronic money, virtual account, agregator, lending, crowdfunding dan transaksi keuangan online lainnya.Adapun fintech yang telah beroperasi.

Saat ini banyak masyarakat sekarang ingin semua berjalan dengan cepat dan mudah, tanpa ada batasan batasan serta aturan -aturan yang ketat oleh karena itu masyarakat beralih ke fintech. Luckandi (2018) melakukan riset tentang analisis transaksi pembayaran menggunakan fintech pada UMKM di Indonesia menyatakan pelaku UMKM untuk menggunakan fintech berkaitan 
PROGRESS

Jurnal Pendidikan, Akuntansi dan Keuangan

Universitas Banten Jaya

dengan faktor pendukung yaitu berupa kemudahan pencatatan, kemudahan proses transaksi serta meningkatkan penjualan, bahwa kenyamanan, keamanan, kesesuaian transaksi serta kemudahan dalam bertransaksi. OJK berfungsi sebagai pengawas dari pemerintah untuk mengatur sektor jasa keuangan misalnya fintech P2P Lending, Crowdfunding, Perbankan Digital, Fintech di pasar modal, Insurtech, pembiayaan online, keamanan data dan perlindungan konsumen. Munculnya inovasi fintech memberikan angin segar untuk pelaku bisnis UMKM sebagai upaya peningkatan dalam pembangunan ekonomi di Indonesia, pertumbuhan ekonomi serta membuka lapangan kerja baru

Fintech membantu pelaku bisnis untuk lebih mudah mendapatkan akses terhadap produk keuangan dan meningkatkan literasi keuangan.Pelaku bisnis bisa memanfaatkan fintech sebagai jalan untuk pembiayaan perusahaannya Peran fintech tidak hanya sebatas dalam pembiayaan modal usaha tetapi merambah ke berbagai aspek seperti layanan pembayaran digital juga pengatur keuangan. Perkembangan teknologi informasi dan komunikasi sejalan kehadiran layanan fintech keuangan berbasis teknologi di Indonesia (Wibowo,
2016).Usaha Mikro Kecil dan Menengah (UMKM) mempunyai peran besar membuka lapangan kerja baru sebagai upaya peningkatan dalam pembangunan dan pertumbuhan ekonomi di Indonesia,.Saat ini, jumlah UMKM di Indonesia terus meningkat dan berkembang dengan bermacam -macam sektor.Dengan peningkatan dan perkembangan dari UMKM diharapkan bisa meningkatkan Produk Domestik Bruto (PDB) dan menyerap lebih banyak tenaga kerja baru serta menekan tingkat pengangguran dan kemiskinan. Karena diberlakukan Masyarakat Ekonomi ASEAN (MEA), yang membuat para pelaku UMKM harus menghasilkan inovasi -inovasi baru sehingga bisa memenuhi tuntutan pasar menyebabkan banyaknya UMKM yang bermunculan membuat persaingan menjadi lebih ketat. Munculnya inovasi fintech memberikan angin segar untuk pelaku bisnis UMKM.

Fintech Fintech menjadikan pelaku bisnis untuk lebih mudah melakukan akses terhadap produk keuangan dan menambah literasi keuangan. Pelaku bisnis bisa menggunakan fintech sebagai pilihan untuk pembiayaan perusahaannya. Berdasarkan penelitian tentang peran fintech terhadap UMKM hasil penelitian dari Irma et al (2018) menyatakan bahwa 
PROGRESS

Jurnal Pendidikan, Akuntansi dan Keuangan

Universitas Banten Jaya

munculnya fintech ikut memberikan kontribusi dalam perkembangan UMKM. Peran fintech bukan hanya sebatas pembiayaan modal usaha tetapi lebih luas ke berbagai aspek seperti layanan pembayaran digital juga pengatur keuangan. Usaha Mikro Kecil dan Menengah (UMKM) di pamekasan saat ini mulai berkembang, namun para pelaku bisnis UMKM masih menggunakan uang tunai dalam bertransaksi. Pembiayaan untuk pengembangan UMKM juga menjadi kendala yang kerap dihadapi oleh pelaku UMKM. Yang disebabkan kurangnya pemahaman terhadap penggunaan dan manfaat fintech yang sangat perlu pemahaman kepada para pelaku UMKM.

Fintech juga turut membantu masyarakat untuk lebih mudah mendapatkan akses terhadap produk keuangan dan literasi keuangan.Industri financial technology (fintech) merupakan salah satu metode layanan jasa keuangan yang mulai naik daun di era digital seperti saat ini.Industri financial technologi (fintech) merupakan salah satu metode layanan jasa keuangan yang mulai populer di era digital sekarang ini.Dan pembayaran digital menjadi salah satu sektor dalam industri FinTech yang paling pesat di Indonesia. Bank Indonesia dalam Peraturan No.19/12/PBI/2017 tentang
Penyelenggaraan Finansial Teknologi dikategorikan ke dalam: (a), pendukung pasar (b) sistem pembayaran, (c) pinjaman, pembiayaan, dan penyediaan modal (d) manajemen investasi dan manajemen risiko, dan (e) jasa finansial lainnya.. Sektor inilah yang paling diharapkan oleh pemerintah serta masyarakat untuk mendorong laju peningkatan jumlah masyarakat yang dapat memiliki akses kepada layanan keuangan (wibowo, 2016).

Fintech pada layanan keuangan misalnya crowdfunding, mobile payments, dan jasa transfer uang menyebabkan perkembangan dalam bisnis startup. Dengan crowdfunding, bisa dapat memperoleh dana dari seluruh dunia dengan cepat dan mudah, bahkan dari orang yang tidak pernah ditemui sekalipun

Fintech juga memungkinkan transfer uang secara global atau internasional. Jasa pembayaran seperti PayPal secara otomatis mengubah kurs mata uang, sehingga yang berada di luar negeri bisa membeli barang dari Indonesia dengan cepat dan mudah, Fintech juga mempunyai peran penting dalam mengubah perilaku dan ekspektasi konsumen diantaranya :

a. dapat mengakses informasi dan data dimana saja 
PROGRESS

Jurnal Pendidikan, Akuntansi dan Keuangan Universitas Banten Jaya

b. Menyamaratakan bisnis kecil dan besar sehingga cenderung untuk memiliki ekspektasi tinggi meski terhadap bisnis kecil yang baru dibangun.

Secara global, industri Fintech terus meningkat dengan pesat.Terbukti dari dengan bermunculannya perusahaan startup di bidang fintech, serta besarnya investasi global di hingga menarik perhatian seluruh pebisnis di Indonesia (Sanjaya, 2016). Financial inclusion (keuangan inklusif) didefinisikan sebagai upaya mengurangi segala bentuk hambatan yang bersifat harga maupun non harga, terhadap akses masyarakat dalam memanfaatkan layanan jasa keuangan (alamsyah, 2016). Sejalan dengan salim (2014) menyatakan Financial inclusion merupakan sebagai bentuk strategi nasional keuangan inklusif yaitu hak setiap orang untuk memiliki akses dan layanan penuh dari lembaga keuangan secara tepat waktu, informatif, terjangkau biayanya, dan, nyaman, dengan penghormatan penuh kepada martabat dan harkat. Global Financial Development Report

mendefinsikan Financial Inclusion sebagai "The proportion of individuals and firms thatuse financial service has become a subject of considerable interest amongpolicy makers, researchers and other stakeholders." financial inclusion merupakan suatu keadaan dimana kenyakan individu dapat mengunakan jasa keuangan yang tersedia serta meminimalisir adanya kelompok individu yang belum paham akan manfaat akses keuangan melalui akses yang telah tersedia tanpa biaya yang tinggi.

Pada UU No. 20 Tahun 2008 tentang Usaha Kecil, Mikro dan Menengah atau yang biasa disingkat UMKM mempunyai definisi sebagai berikut:

1. Usaha Mikro adalah usaha produktif milik orang perorangan dan/atau badan usaha perorangan yang memenuhi kriteria Usaha Mikro sebagaimana diatur dalam UndangUndang yaitu memiliki kekayaan bersih paling banyak Rp50.000.000,00 (lima puluh juta rupiah) tidak termasuk tanah dan bangunan tempat usaha; atau memiliki hasil penjualan tahunan paling banyak Rp300.000.000,00 (tiga ratus juta rupiah).

2. Usaha Kecil adalah usaha ekonomi produktif yang berdiri sendiri, yang dilakukan oleh orang perorangan atau badan usaha yang bukan merupakan anak perusahaan atau bukan cabang perusahaan yang dimiliki, dikuasai, atau menjadi bagian baik langsung maupun tidak langsung dari Usaha Menengah atau Usaha Besar yang 
PROGRESS

Jurnal Pendidikan, Akuntansi dan Keuangan

Universitas Banten Jaya

memenuhi kriteria Usaha Kecil

sebagaimana dimaksud dalam

Undang-Undang yaitu memiliki

kekayaan bersih lebih dari

Rp50.000.000,00 (lima puluh juta

rupiah) sampai dengan paling banyak

Rp500.000.000,00 (lima ratus juta rupiah) tidak termasuk tanah dan bangunan tempat usaha; atau memiliki hasil penjualan tahunan lebih dari Rp300.000.000,00 (tiga ratus juta rupiah) sampai dengan paling banyak Rp2.500.000.000,00 (dua milyar lima ratus juta rupiah).

3. Usaha Menengah adalah usaha ekonomi produktif yang berdiri sendiri, yang dilakukan oleh orang perorangan atau badan usaha yang bukan merupakan anak perusahaan atau cabang perusahaan yang dimiliki, dikuasai, atau menjadi bagian baik langsung maupun tidak langsung dengan Usaha Kecil atau Usaha Besar dengan jumlah kekayaan bersih atau hasil penjualan tahunan sebagaimana diatur dalam Undang-Undang yaitu memiliki kekayaan bersih lebih dari Rp500.000.000,00 (lima ratus juta rupiah) sampai dengan paling banyak Rp10.000.000.000,00 (sepuluh milyar rupiah) tidak termasuk tanah dan bangunan tempat usaha; atau memiliki hasil penjualan tahunan lebih dari
Rp2.500.000.000,00 (dua milyar lima ratus juta rupiah) sampai dengan paling banyak Rp50.000.000.000,00 (lima puluh milyar rupiah).

UMKM mempunyai peranan penting dan strategis dalam pembangunan ekonomi nasional.Selain berperan dalam pertumbuhan ekonomi dan penyerapan tenaga kerja, UMKM juga berperan dalam mendistribusikan hasil-hasil pembangunan.

\section{METODE}

\section{Jenis Penelitian}

Metode penelitian kualitatif adalah metode penelitian yang berbedasarkan paradigma interpretatif dan konstruktif, atau pada filsafat post positivisme, yang memelihat realitas sosial sebagai sesuatu yang utuh atau holistik, dinamis, kompleks, penuh makna dan hubungan gejala bersifat interaktif dan digunakan untuk meneliti pada kondisi obyek yang alamiah, bukan eksperimen, dimana peneliti sebagai instrumen kunci, teknik pengumpulan data dilakukan secara triangulasi (gabungan), analisis data bersifat kualitatif atau induktif dan hasil penelitian menekankan makna dari pada generalisasi Penelitian ini menggunakan metode kualitatif karena peneliti ingin menganalisis dan mengetahui secara 
PROGRESS

Jurnal Pendidikan, Akuntansi dan Keuangan

Universitas Banten Jaya

mendalam tentang Peran fintech dalam meningkatkan keuangan inklusif pada UMKM di Indonesia. Adapun pendekatan yang digunakan dalam penelitian ini adalah pendekatan keuangan.

\section{Sumber Data}

Sumber data Menurut

Lofland dalam Moleong (2017) penelitian kualitatif ialah, tindakan dan kata- kata, selebihnya adalah data pendukung seperti dokumen dan lain-lain. Pada penelitian ini sumber data diperoleh dari:

1. Data primer adalah data yang diperoleh langsung dari objek penelitian, dalam hal ini penulis memperoleh langsung dari nara sumber yaitu staf dinas koperasi dan UMKm pamekasan dan 3 orang pelaku UMKM yang menjadi informan dalam penelitian ini.

2. Data sekunder adalah data yang diperoleh dalam bentuk data yang sudah jadi, data ini diperoleh dari dokumen-dokumen terkait misalnya artikel, buku, dan foto.

\section{Teknik Analisis Data}

Teknik analisis data yang digunakan dalam penelitian ini adalah model interaktif. analisa dengan menggunakan analisis model interaktif dilakukan melalui tiga prosedur, yaitu:

\section{Reduksi Data}

Merupakan proses pemusatan penyederhanaan, perhatian, dan penilaian, pengabstrakan dan transformasi data yang muncul dari catatan tertulis di lapangan. Teknik analisis ini diperlukan peneliti agar mengarahkan dan menajamkan analisis dengan menggolongkanya danmembuang yang tidak diperlukan.

\section{Penyajian Data}

Adapun informasi yang ditampilkan dan memberikan kemungkinan tentang adanya penggunaan kesimpulan dan mengambil tindakan. Bentuknya dapat menggunakan skema atau gambaran dari tabel yang dirancang untuk menyususn agar dapat dipahami. Teknik analisis inidiperlukan oleh peneliti untuk memudahkan peneliti dalam melihat gambaran secara umum tentang apa yang sedang terjadi atau hasil datayang diperoleh selama penelitian sehingga dapat ditentukan apa yangselanjutnya harus dilakukan oleh peneliti.

\section{Menarik}

Kesimpulan

\section{(Verifikasi)}

Data-data yang telah dikumpulkan dan dianalisis tersebut dapat di tarik kesimpulan-kesimpulan. Penarikan kesimpulan dilakukan selamapenelitian berlangsung. Teknik analisis data dengan menarik kesimpulanini peneliti akan 
PROGRESS

Jurnal Pendidikan, Akuntansi dan Keuangan

Universitas Banten Jaya

memberikan kesimpulan dari hasil analisis data yang telahdilakukan serta memberikan saran-saran sebagai rekomendasi lanjutanuntuk kebijakankebijakan mengenai peran koperasi wanita dalammembangun keuangan inklusif syariah.

Alasan pemilihan teknik analisis data menggunakan model interaktif yaitu karena model tersebut akan memudahkan peneliti. Data-data yangtelah diperoleh dilapangan akan diseleksi terlebih dahulu, setelah itudisajikan dalam laporan penelitian dengan memberikan analisaanalisasebelum dilakukan langkah yang terakhir yaitu menarik kesimpulan.

\section{HASIL DAN PEMBAHASAN}

Penerapan fintech oleh pelaku UMKM setelah dianalisis, ternyata melalui proses yang panjang serta banyak pertimbangan untuk pada akhirnnya mengambil keputusan tersebut. Para pelaku UMKM tidak serta merta pada saat memulai usahanya, langsung menggunakan fintech pada tempat usahanya.Perlu adanya pandangan serta persepsi kepada berbagai macam strukutrasi yang telah dipetakan oleh AST, yang pada kenyataanya strukutrasi serta kococokan tersebut mempengaruhi hasil akhir untuk menerapkan fintech.Secara keseluruhan, pelaku
UMKM pada penelitian ini tidak melakukan resistensi secara berlebihan terhadap penggunaan fintech.Dengan berbagai persepsi meliputi permintaan pelanggan, permintaan pasar, kemudahan, serta perkembangan zaman, kenyataanya perlu diperhatikan agar penerapan ini memiliki hasil yang baik di kemudian hari.Karena ada berbagai konsekuensi yang harus diperhatikan setelah menerapkan teknologi ini. Berikut adalah hasil dari analisis penerapan fintech sebagai sarana pembayaran pada pelaku UMKM dengan menggunkan pendekatan triangulasi.

Hal pertama utama menjadi kata kunci dalam penerapan teknologi ini adalah kemudahan. Fintech dinilai dapat memberikan kemudahan terhadap proses bisnisnya. Dengan mengabaikan konsekuensi pada awalnya, kemudahan menjadi hal yang istimewa yang dianggap pelaku UKM sebagai percepatan roda bisnis mereka.Kemudahan tersebut berupa pencatatan transaksi, fitur transfer ke rekening, serta pasar yang dijanjikan.Sudah dibayangkan jika mendapatkan fitur tersebut, tentu tugas pelaku UKM menjadi lebih ringan dengan keuntungan yang dapat diperhitungkan di awal .Dengan menerapkan fintech, mungkin pelaku UKM berpikir tidak perlu untuk menambah karyawan pada 
PROGRESS

Jurnal Pendidikan, Akuntansi dan Keuangan Universitas Banten Jaya

bagian keuangan karena pencatatan keuangan sudah ditangani oleh fintech. Selanjutnya dengan fitur uang elektronik yang masuk ke rekening secara otomatis, tentu akan mepermudah tugas setiap harinya untuk penyetoran ke bank, dengan berbagai penghematan yang dapat muncul.

Setelah melakukan pertimbangan, ternyata timbul konsekuensi yang ada di balik kemudahan tersebut.Konsekuensi terbesar adalah biaya yang muncul akibat penggunaan fitur tersebut.Biaya tersebut muncul, karena perusahaan fintech GoJek menawarkan fitur layanan pesan antar kepada pelaku UKM. Tentu akan muncul sebuah aplikasi untuk menangani fitur tersebut, dan penawaran fitur tersebut ternyata tidak cuma-cuma. Pada awalnya, mungkin angka yang ditawarkan dirasa memberatkan, timbul penolakan dari pelaku UMKM, karena secara hitungan kurang memadai.Ternyata di balik penolakan tersebut, timbul permintaan pelanggan kepada pelaku UMKM untuk menawarkan produknya melalui penyelengara tersebut.Atas desakan dan permintaan, pelaku UMKM akhirnya mencoba menggunakan fitur tersebut. Atau skenario lain, ada pelaku UMKM yang dari awalnya sudah langsung menggunakan layanan fintech tersebut karena sudah menggunakan secara pribadi, atau pengaruh lingkungan sosial, seperti lingkungan sesama pengusaha misalnya. Ternyata setelah menggunakan, fitur tersebut dirasa tidak memberatkan. Pelaku UMKM dapat melakukan penyesuaian harga pada produknya untuk mendapatkan keuntungan yang ditawarkan dari penyelenggara tersebut.

Seiring dengan perjalanan waktu, penggunaan fintech semakin tidak memberatkan.Terlebih dengan berbagai keuntungan yang ditawarkan, fintech dirasakan dapat menjadi mitra bagi pelaku UMKM dalam menjalankan bisnisnya. Kemudahan yang menjadi awal alasan pelaku UMKM menggunakan fintech ternyata berjalan dengan baik.Berbagai kemudahan memang pada kenyataanya berdampak kepada bisnisnya.Kemudahan seperti fitur promosi, layanan pesan antar menjadi hal yang sehari-hari berdampak pada bisnis mereka. Hal ini tentunya akan berdampak kepada bisnis yaitu akan mendapatkan peningkatan pada bisnisnya. Hal lain yang berdampak adalah kurangnya kecurangan setelah menggunakan fintech (luckandi, 2018). Hal ini berdampak nyata, karena dengan adanya fintech, semua transaksi tercatat secara computerized. Tentu ini akan memudahkan pelaku UMKM dalam mencocokkan transaksi serta melakukan stock opname. Berbagai keuntungan 
PROGRESS

Jurnal Pendidikan, Akuntansi dan Keuangan

Universitas Banten Jaya

serta dampak di atas, tidak akan terjadi dan tidak ada keselarasan internal pada organisasi pelaku UMKM. Pelaku UKM dimudahkan dengan keakraban karyawan mereka dengan teknologi ini.Ternyata, kebanyakan karyawan mereka telah terbisasa menggunakan fintech pada kehidupan sehari-harinya. Hal ini tentu akan memudahkan proses penggunan teknologi ini. Setelah mencapai kesepahaman, maka akan mendukung sisi ekonomis dan teknis (wibowo, 2016) dalam penerapan teknologi ini. Pelaku usaha tidak perlu mengalami kesulitan dalam mengenalkan teknologi ini.Setelah karyawan mahir dalam menggunakan, maka konflik dapat teratasi dengan baik. Ini kembali lagi akan memotivasi peningkatan bisnis secara ekonomis. Kenyataanya, kemahiran dalam menggunakan suatu teknologi memang akan berdampak pada bisnis. Penerapan fintech pada UMKM ternyata dapat membuat sebuah budaya baru (sanjaya, 2016) dalam kehidupan sehari-hari.Dari hasil wawancara yang didapatkan, banyak kaum ibu yang khususnya sedang mempunyai anak kecil terbantu dengan adanya fitur ini. Dengan adanya teknologi ini, para masyarakat dengan mudah untuk melakukan suatu pesanan pada produk tertentu. Dengan kondisi khusus para masyarakat tidak perlu meninggalkan rumah untuk mengambil uang di ATM untuk membayar produk pesanannya.

Hasil dari penggunaan fintech pada pelaku UMKM adalah berupa kelebihan yang memberikan nilai positif untuk kemajuan bisnisnya. Pada penerapannya, berbagai faktor yang memperngaruhi proses implementasi yang banyak dipengaruhi oleh faktor eksternal yang secara stratregis belum dipikirkan oleh pelaku UMKM. Faktor tersebut adalah perilaku pasar yang secara tidak langsung memaksa pelaku UMKM untuk segera menerapkan fintech demi kelangsungan bisnisnya. Pasar yang sudah praktis, akan mulai beralih pada metode pembayaran maupun transaksi yang dilakukan dengan konvensional, hal ini tidak akan memberatkan maysrakat dalam melakukan pembayaran elektronik. Penerapan fintech justru membuat para pengusaha UMKM untuk tetap memikirkan inovasi dan strategi apa yang dilakukan untuk mengiringi penerapan fintech ini. Pelaku UMKM harus memikirkan bagaimana strategi yang cocok agar fintech dapat menjadi patner yang menguntungkan bisnisnya. Sikap resisten terhadap teknologi ini membuat pengusaha UMKM akan kehilangan porsi pasar, walau tidak keseluruhan. Dari berbagai fitur yang ditawarkan, fintech dapat menjadi pendukung perkembangan 
PROGRESS

Jurnal Pendidikan, Akuntansi dan Keuangan

Universitas Banten Jaya

pasar serta menggerakkan bisnis bagi pelaku UMKM.

\section{Faktor Pendukung dan Penghambat}

Setelah melaksanakan tahapan analisis, dengan strukturisasi serta kecocokan yang terjadi pada penelitian ini, maka dapat dikelompokkan mengenai faktor yang menghambat dan mendukung penerapan serta penggunaan fintech sebagai transaksi pembayaran pada UMKM. Faktor-faktor ini dikelompokkan berdasarkan reaksi atau sentimen yang didapatkan dari hasil analisis

\section{Faktor Pendukung}

\section{a) Kenyamanan}

Kenyamanan dalam menggunakan fintech (rizal, 2018) menjadi faktor utama bagi pelaku UMKM untuk menerapkan fintech sebagai sarana transaksi pembayaran. Dengan menggunakan fintech, pelaku UMKM dapat dengan nyaman menjalankan bisnisnya tanpa perlu khawatir akan terjadinya kesalahan serta mempermudah tugas dalam menjalankan bisnisnya. Hal ini pun berdampak kepada pelanggan yang mendapatkan kenyamanan dalam bertransaksi. Dengan adanya kenyamanan ini, maka ketidakpercayaan terhadap epayment (luckandi, 2018) akan sedikit demi sedikit berkurang untuk mencapai hal yang positif. Fintech sebagai sarana manajemen konflik menjadi parameter kenyamanan yang ditimbulkan oleh fintech. Dengan adanya fintech, maka konflik yang biasa atau akanterjadi dapat diminimalisir. Parameter lain adalah pengetahuan karyawan. Pengetahuan karyawan dapat memberikan kenyamanan dan memperkecil kesulitan pada saat menerapkan fintech pada perusahaannya.

\section{b) Keamanan}

Dengan banyaknya insiden cyber fraud, maka menjadikan alasan penggunanya untuk menerapkan layanan e-payment (luckandi, 2018).Pelaku UKM mempercayakan aset serta pencatatannya untuk dikelola oleh penyelenggara fintech.Pada kenyataanya, pelaku UKM menaruh uang serta transaksinya kepada penyelenggara fintech dalam bentuk uang elektronik, atau pada kemudian waktu dilakukan pemindahan ke rekening bank.Hal ini tentu didasari dengan rasa keamanan untuk mempercayakan transaksinya kepada penyelenggara fintech.

\section{c) Kesesuaian Transaksi}

Pelaku UKM merasakan bahwa dengan melakukan transaksi secara computerized, maka akan memberikan fitur dan keuntungan lebih serta mengurangi resiko kesalahan manusia. Faktor kesesuaian transaksi ini menjadi 
PROGRESS

Jurnal Pendidikan, Akuntansi dan Keuangan

Universitas Banten Jaya

faktor utama pelaku UKM untuk menggunakan fintech sebagai sarana transaksi. Pelaku UKM percaya bahwa dengan menggunakan fintech, maka akan dapat mengurangi kesalahan serta fraud yang biasa terjadi pada transaksi konvensional. Maka finech dapat memberikan keuntungan jika dibandingkan dengan transaksi tunai (Adeyelure, Pretorius, \& Kalema, 2014).

\section{d) Kemudahan}

Berbagai fitur ditawarkan seiring dengan penggunaan fintech pada bisnis para pelaku UKM.Hal ini membawa nilai positif berupa kemudahan dari berbagai sudut tugas dalam menjalankan bisnisnya.Fintech menawarkan fitur yang pada awalnya memberikan first impression yang baik kepada penggunanya (wibowo, 2016), meliputi pelaku UKM serta pelanggannya.Hal ini menjadi candu bagi mereka karena berbagai kemudahan yang ditawarkan, membuat pelaku UMKM sendiri menerapkan fintech pada bisnis mereka.

\section{e) Bisnis}

Fakta menunjukkan bahwa penerapan fintech oleh pelaku UKM murni untuk keberlangsungan bisnisnya.Pelaku UKM memutar otak untuk melakukan inovasi, sampai pada akhirnya salah satunya dengan menerapkan fintech pada bisnisnya.Bisnis menjadi faktor yang semata-mata penting, karena tentu saja hal ini berkaitan dengan dunia usaha bagi para pelaku UKM. Jika fintech tidak menguntungkan secara bisnis; walau dengan berbagai keuntungan yang sudahdisebutkan, tentu saja fintech tidak akan diterapkan oleh pelaku UKM. Pada kenyataanya, diperlukan kesadaran oleh pelaku UMKM itu sendiri untuk menerapkan fintech pada bisnisnya (wibowo, 2016). Hal ini akan berdampak positif terhadap bisnisnya.

\section{Faktor Penghambat}

\section{a) Implementasi Teknologi}

Pada saat melakukan implementasi teknologi, awalnya menjadi momok bagi pelaku UKM karena tidak semua anggota organisasi atau karyawannya terbiasa dengan teknologi.Perlu ada penanganan tersendiri bagi pelaku UKM untuk mengenalkan teknologi fintech kepada karyawannya, karena hal ini berkaitan dengan keuangan bagi perusahaan.Setelah dilakukan, ada pelaku usaha yang berhasil menangani faktor ini, ada pula kesalahan-kesalahan yang masih timbul setelah implementasi teknologi dilakukan pada usahanya. Faktor ini juga dapat menjadi alasan bagi pelaku usaha untuk tidak menerapkan teknologi fintech pada usahanya. 
PROGRESS

Jurnal Pendidikan, Akuntansi dan Keuangan Universitas Banten Jaya

\section{b) Biaya}

Biaya menjadi salah satu faktor yang menjadi penghambat bagi pelaku UKM untuk menerapkan fintech sebagai sarana transaksi pada usahnya.Untuk menerapkan fintech, perlu ada biaya yang dikeluarkan oleh pelaku UMKM.Pada akhirnya, biaya tidak menjadi faktor yang terlalu berat, karena dapat ditangani dengan melakukan penyesuaian harga pada produknya. Dengan meningkatnya pendapatan yang timbul akibat penerapan fintech pada usahanya, factor ini dirasakan tidak terlalu mengganggu sesuai dengan hasil analisis di lapangan.

\section{c) Kesiapan Infrastruktur}

Faktor ini menjadi sangat penting, karena peran dari pemerintah sangat mendukung penggunaan fintech sebagai sarana transaksi elektronik. Dengan terbatasnya persediaan instrument pembayaran elektronik (rahma, 2018), maka akan juga dapat menghambat penggunaan fintech di kalangan pelaku usaha. Dengan infrastruktur yang stabil dan tersebar, serta dengan peraturan kerangka kerja yang jelas (kennedy, 2017) dari pemerintah, maka penyerapan penggunaan fintech di masyarakat akan dapat meningkat, dan dapat memberikan nilai positif yang diharapkan saat menggunakan teknologi ini.

\section{d) Pola Penerapan Fintech pada UMKM}

Untuk mendapatkan pola penerapan fintech, akan dilakukan penangkapan terhadap alur yang diperoleh pada hasil wawancara, serta data observasi yang didapatkan pada saat dilakukan wawancara. Selanjutnya data dan alur observasi yang didapatkan dari 3 organisasi tersebut akan digabungkan, untuk disusun menjadi sebuah pola yang dapat mewakili proses penerapan pada sektor ini.

Hasil observasi ini lalu ditemukan irisannya untuk membentuk pola penerapan fintech yang terjadi dari narasumber.Berikut adalah pola penerapan fintech pada pelaku UMKM pada sector.Dalam menerapkan fintech, terdapat kebutuhan yang muncul sebelumnya sampai akhirnya pelaku UMKM memutuskan untuk menerapkan fintech. Keputusan tersebut didukung oleh penyedia layanan, serta informasi dari sesama pelaku usaha.Setelah menerapkan, timbul resistensi terhadap biaya yang muncul dari penerapan layanan fintech.Pelaku usaha perlu melakukan penyesuaian harga terhadap produknya.Pada akhirnya, pelaku usaha mempertahankan layanan yang menguntungkan usahanya. 


\section{KESIMPULAN}

Kehadiran sejumlah perusahaan fintech turut berperan dalam pengembangan UMKM. Tidak hanya sebatas sebagai pembiayaan modal usaha, peran Fintech juga sudah memperluas ke berbagai aspek seperti layanan pembayaran digital dan pengaturan keuangan Kendala implementasi fintech dalam meningkatkan keuangan inklusif pada UMKM di Indonesia

1. Infrastruktur

2. Sumber Daya Manusia (SDM)

3. Perundang-undangan

4. Kurangnya literasi keuangan

\section{REFERENSI}

Alamsyah Halim, (2016). "Pentingnya Keuangan Inklusif dalam Meningkatkan Akses Masyarakat dan UMKM terhadap Fasilitas Jasa Keuangan Syariah".

Cooper. Donald dan Schindler, 2017, "Metode Penelitian Bisnis" Edisi Dua Belas Buku Satu. Jakarta: Salemba Empat FSB, 2017, "Financial Stability Implications from Fintech", http://www.fsb.org/wpcontent/uploads/R270617.pdf/.

Global Financial Development Report 2014 : Financial Inclusion. Washington, DC. (C) World Bank. https://openknowledge.worldbank .org/handle/10986/16238 License: CC BY 3.0 IGO."

Imanuel Adhitya Wulanata Chrismantianto, 2017. Analisis SWOT Impementasi Teknologi
Finansial Terhadap Kualitas Layanan Perbankan di Indonesia, Jurnal Ekonomi dan Bisnis Volume 20 No. 1.

Irma Muzdalifah. Inayah Aulia dan Bella Gita, 2018, "Peran Fintech dalam Meningkatkan Keuangan Inklusif pada UMKM di Indonesia" Jurnal Masharif-Syariah Vol. 3, No. 1. Universitas Muhammadiyah Surabaya

Kennedy P.S. J, (2017), Tantangan terhadap Ancaman Disruptif dari Financial Technology dan Peran Pemerintah dalam Menyikapinya, Prosiding Forum Keuangan Dan Bisnis Indonesia (FKBI)

Kim, Yonghee J., 2015, “An Empirical Study on the Adoption of "Fintech" Service: Focused on Mobile Payment Services". Advanced Science and Technology Letters Vol.114 (Business 2015), pp.136-140.,

Luckandi. Diardo, 2018, “Analisis Transaksi Pembayaran Menggunakan Fintech Pada UMKM di Indonesia: Pendekatan Adaptive Structuration Theory", Tesis. Universitas Islam Indonesia

Moleong, Lexy J. (2017). Metode Penelitian Kualitatif, cetakan ke36, Bandung : PT. Remaja Rosdakarya Offset

Peraturan Bank Indonesia nomer 19/12/PB/2017 tentang penyelenggaraan financial tec hnologi (PBI Tekfin).

Rahma, T.I.F, (2018), Persepsi Masyarakat Kota Medan Terhadap Penggunaan Financial Technology, At-Tawassuth: Jurnal Ekonomi Islam, vol 3 (1) 642-661 
Rizal muhamad, dkk, (2018), Fintech As One Of The Financing Solutions For SMEs, AdBispreneur : Jurnal Pemikiran dan Penelitian Administrasi Bisnis dan Kewirausahaan, Vol. 3(2), 89100.

Salim Meilisa et.al, (2014).Analisis Implementasi Program Financial Inclusion Di Wilayah Jakarta Barat Dan Jakarta Selatan (Studi pada Pedagang Golongan Mikro, Instansi Perbankan, Otoritas Jasa Keuangan dan Bank Indonesia), [Skripsi], Universitas Bina Nusantara.

Sanjaya Made, 2016 Inklusi Keuangan Dan Pertumbuhan Inklusif Sebagai StrategPengentasan Kemiskinan Di Indonesia.

Sari P.P \& Septiyarini, E, (2018), Pengaruh Financial Technology Terhadap Kepuasan Keuangan, urnal UMKM Dewantara Vol. 1(1), 20-28

UU No. 20 Tahun 2008 tentang Usaha Kecil, Mikro dan Menengah

Wibowo. Budi, 2016, “Analisa Regulasi Fintech dalam Membangun Perekonomian di Indonesia" Program Magister Teknik Elektro. Universitas Mercu Buana. 
PROGRESS

Jurnal Pendidikan, Akuntansi dan Keuangan Universitas Banten Jaya
Vol 4 No. 2, Agustus 2021

E-ISSN 2622-7037 |P-ISSN 2623-0763 